\title{
GENETIC DIVERSITY OF E. COLI O157:H7 ISOLATED FROM ALEPPO RIVER WATER SAMPLES USING RANDOM AMPLIFIED POLYMORPHIC DNA (RAPD) MARKER
}

\author{
Darkazanli M. ${ }^{1^{*}}$, Kiseleva I.C. ${ }^{1}$, Darkazanli K. ${ }^{2}$ \\ 1) Ural Federal University, Yekaterinburg, Russia \\ 1) Zhejiang Normal University, Jinhua, China \\ *E-mail: mdarkazanli@urfu.ru
}

In Syria, there is not a lot of research that studies E. coli, and its serotypes by PCR technology. Escherichia coli O157:H7 is a very important serotype, and one of the Shiga toxin producing (classified as a bioterrorism agent) [1]. So, we detected E. coli and especially serotype $E$. coli $0157: H 7$ in water samples that were taken from villages passed by river. Sites of village: Handarat (A), Industrial Zone (B), Souq Al-hal (C), Bustan Palace area (D), Al-sheikh Saeed (E), Al-wodaihi (F), Zietan (G), and Jezraya (H).

In this study, we have fulfilled a total count of bacteria, the census total coliform, and Escherichia coli, as well as the serotype E. coli O157:H7 in water samples by different Bacterial Media. For DNA Extraction we used Protocol for Preparation of Genomic DNA from Bacteria [2]. The molecular characterization was done for eight strains of $E$. coli isolated from collected samples from the sites of all villages then we used a primer (COL-1) in RAPD technic. Molecular characterization also performed eight strains of serotype E. coli O157:H7 from the following sites (Al-sheikh Saeed, Al-wodaihi, Zietan, and Jezraya), then by primers (OPA-03, OPA-13 OPC-12, OPE20) in RAPD.

The results showed significant differences between the collected samples. The total count of bacteria and total coliforms in the first site (Handarat) were the lowest, but in the last site (Jezraya) were the highest among all samples, at the beginning of village Jezraya the wastewater from the sewage treatment station and all villages flows to the main river, and it increased the bacteria. The results showed also the existence of $E$. coli in all sites, and E. coli O157:H7 in Al-sheikh Saeed, Al-wodaihi, Zietan, and Jezraya.

Extracted DNA from samples was amplified by RAPD. after electrophoresis, eight different bands were detected from isolated strains of $E$. coli. These results refer to the great genetic diversity of Escherichia coli also Maurer et al. (1998) found (16) different RAPD types in $84 \% E$. coli isolates which agree with our results [3]. For serotype $E$. coli O157:H7 thirty-two different bands were detected, and primer OPA-13 was the best primers used, RAPD analysis had the high discriminatory capacity for typing $E$. coli isolates. Because of its simplicity and rapidity. 
ФТИ-2019

Number of bands and polymorphism revealed by RAPD

\begin{tabular}{|c|c|c|c|c|}
\hline Primer code & $\begin{array}{c}\text { Nucleotide } \\
\text { sequence, min- } \\
\text { max }\end{array}$ & $\begin{array}{c}\text { Total scorable } \\
\text { bands }\end{array}$ & $\begin{array}{c}\text { No. of } \\
\text { polymorphic } \\
\text { bands }\end{array}$ & $\begin{array}{c}\text { polymorphic } \\
\text { bands, \% }\end{array}$ \\
\hline COL-1 & $10-750$ & 25 & 8 & 32 \\
\hline OPA-03 & $200-3000$ & 26 & 7 & 26.9 \\
\hline OPA-13 & $500-5500$ & 45 & 13 & 28.88 \\
\hline OPC-12 & $1500-\mathrm{b}$ & 33 & 9 & 27.27 \\
\hline OPE-20 & $3500-^{b}$ & 9 & 3 & 33.3 \\
\hline
\end{tabular}

1. Heijnen L., and Medema G., J. Water Health., 4, 487-498 (2016).

2. Maloy S.R., Experimental Techniques in Bacterial Genetics., Jones \& Bartlett Learning., (1989).

3. Maurer J.J., Lee M.D. et al., Avian Disease., 42., 431-451 (1998). 